Check for updates

Cite this: RSC Adv., 2017, 7, 37359

\section{Comparison of anticancer activity and antioxidant activity between cyanidin-3-O-glucoside liposomes and cyanidin-3-O-glucoside in Caco-2 cells in vitro}

\author{
Tisong Liang, (D) $\dagger^{\mathrm{a}}$ Rongfa Guan, (D) $\dagger^{\star a}$ Zhe Wang, $^{\mathrm{a}}$ Haitao Shen, ${ }^{\mathrm{b}}$ Qile Xia ${ }^{\mathrm{c}}$ \\ and Mingqi Liu ${ }^{a}$
}

In this study, we compared the antioxidant activities of cyanidin-3-O-glucoside (C3G) and C3G liposomes. We also compared the anticancer activities of C3G and C3G liposomes in Caco-2 cells. The radical scavenging activity of 2,2-diphenyl-1-picrylhydrazyl and the scavenging activity of 2,2'-azinobis-3ethylbenzthiazoline-6-sulfonic acid were used to evaluate the antioxidant activity of C3G and C3G liposomes. In addition, cell morphology, Cell Counting Kit-8 (CCK-8) assay, the microscopic structure of cells, and flow cytometry analysis were used to evaluate their anticancer activities. The CCK- 8 assay results demonstrated that $\mathrm{C} 3 \mathrm{G}$ and $\mathrm{C} 3 \mathrm{G}$ liposomes reduced the mitochondrial activity of cells through dose effect, and the viabilities of Caco-2 cells were significantly decreased in vitro following exposure to C3G liposomes at 0.20 and $0.25 \mathrm{mg} \mathrm{mL}^{-1}$ concentrations. The microscopic structure of cells exhibited the changes in the numbers and structures of mitochondria and fat droplet and the appearance of physalides, there by indicating that C3G liposomes affects the microscopic structure of cells. The CCK- 8 evaluation of cell proliferation and the FCM analysis supported the anti-proliferative effects of C3G liposomes. Results demonstrated that the presence of C3G liposomes was more significant than that of C3G in inhibiting the proliferation of human tumor cells. Therefore, C3G liposomes have a potential therapeutic modality in tumor management.
Received 7th June 2017 Accepted 11th July 2017 DOI: $10.1039 / c 7 r a 06387 c$ rsc.li/rsc-advances the apoptosis of cancer cells, reduces oxidative stress, fights $\mathrm{H}_{2} \mathrm{O}_{2}$ induced oxidative stress in human embryonic kidney (HEK-293) cells, and induces cell apoptosis and inhibits cell migration in TNF-a-challenged RASMCs in vitro. ${ }^{\mathbf{1 0}-16}$ Fratantonio found that C3G pretreatment effectively reverses the effects of PA on the PI3K/Akt axis and restores the eNOS expression and NO release. ${ }^{17}$ Sivasinprasasn revealed that pretreatment with $\mathrm{C} 3 \mathrm{G}$ inhibits the NF- $\kappa \mathrm{B}$ signaling pathway. ${ }^{18}$

Liposomes are vesicles in which small aqueous volumes are surrounded by bilayer membranes that are normally composed of phospholipids. ${ }^{19}$ Liposomes enhance the stability and activity of encapsulated materials by protecting them from the environment and liposomes can protect and improve the activity of bioactive compounds, which makes them ideal candidates for drug delivery and enhancing antitumor immunization $\mathrm{y},{ }^{\mathbf{2 0 - 2 5}}$ numerous research on the application of liposomes as protective membranes in food and pharmacological systems exist. ${ }^{26-29}$ Several studies showed that liposomes can improve the bioavailability of lecithin and can be used as carriers in food systems. ${ }^{30-32}$

We used the liposome technology because liposomes can protect embedding materials and thus improve the effectiveness and stability of $\mathrm{C} 3 \mathrm{G}$, which could be used as a carrier. 
The objectives of this study were to compare the anticancer and antioxidant properties of $\mathrm{C} 3 \mathrm{G}$ and $\mathrm{C} 3 \mathrm{G}$ liposomes by assessing the cellular viability in Caco-2 cells exposed to $\mathrm{C} 3 \mathrm{G}$ and C3G liposomes. We compared the antioxidant properties of C3G and C3G liposomes through the radical scavenging activity of 2,2-diphenyl-1-picrylhydrazyl (DPPH) and the ABTS scavenging assay. We also evaluated the structure, morphology change, proliferation, and apoptosis of the cells treated with C3G liposomes using Cell Counting Kit-8 (CCK-8), transmission electron microscope (TEM), and FCM.

\section{Materials and methods}

\subsection{Materials}

The Caco-2 cells (CBCAS, Shanghai, China) and C3G were purchased from Chengdu Biopurify Phytochemicals Ltd. (Chengdu, China). Phosphatidylcholine (PC) and cholesterol $(\mathrm{CH})$ were purchased from Beijing Shuangxuan Microorganism Co. Ltd. (Beijing, China). Chloroform and diethyl ether were obtained from Hangzhou Jiachen Chemical Company (Hangzhou, China). All other chemicals were reagent-grade. Deionized water was used in all experiments.

\subsection{Methods}

2.2.1 Preparation of G3G liposomes. C3G liposomes were prepared by the reverse-phase evaporation method. ${ }^{33,34}$ Phosphatidylcholine (PC) and cholesterol $(\mathrm{CH})$ were dissolved in chloroform-diethyl ether $\left(W_{\mathrm{PC}}: W_{\mathrm{CH}}=2.87: 1\right)$. C3G was dissolved in PBS $(0.20 \mathrm{M}, \mathrm{pH} 7.4)$. Then, the organic phase was homogenized with the aqueous phase by probe sonication for $10 \mathrm{~min}$. The mixture was transferred to a round-bottomed flask. The organic solvent was evaporated under reduced pressure with a rotary evaporator to form a gel. Then, $30 \mathrm{~mL}$ of phosphate-buffered solution was added to the gel, which was then probe-sonicated for an additional $25 \mathrm{~min}$. The as-prepared liposomes were stored at $4{ }^{\circ} \mathrm{C}$ for further study.

2.2.2 Morphology and size of the liposomes. A transmission electron microscope (JEM-2100, Japanese Electronics Co., Ltd., Tokyo, Japan) and a particle size analyzer (Zetasizer NanoZS 90, Malvern Company, Malvern, UK) were employed to determined the microstructure and size of the C3G liposomes. A drop of liposomes was placed on a Formvar carbon-coated copper grid using the negative staining method (200 mesh, 3 $\mathrm{mm}$ diameter HF 36) for $5 \mathrm{~min}$, and then to the image. ${ }^{35}$

\subsubsection{Antioxidant assay}

2.2.3.1 Radical scavenging activity of 2,2-diphenyl-1picrylhydrazyl (DPPH). The radical scavenging activity of 2,2diphenyl-1-picrylhydrazyl (DPPH) was measured according to a previously described method with a few modifications. ${ }^{36}$ Briefly, $2 \mathrm{~mL}$ of DPPH solution $\left(0.2 \mathrm{mmol} \mathrm{L}^{-1}\right.$, in ethanol) was mixed with $2 \mathrm{~mL}$ of the sample at different concentrations $\left(0.015,0.020,0.025,0.030,0.035\right.$, and $\left.0.040 \mathrm{mg} \mathrm{mL}^{-1}\right)$. Then, the solution was thoroughly mixed and kept in the dark at room temperature for $30 \mathrm{~min}$ before evaluating its absorbance at $517 \mathrm{~nm}$ using a spectrophotometer. Ethanol was used as the control. The DPPH radical scavenging activity of the sample was determined using the following formula: ${ }^{37,38}$

$$
\begin{aligned}
& \text { DPPH radical scavenging activity }= \\
& \left(\frac{A_{517} \text { blank }-A_{517} \text { sample }}{A_{517} \text { blank }}\right) \times 100 \%,
\end{aligned}
$$

where $A_{517}$ is the absorbance measured at $517 \mathrm{~nm}$.

2.2.3.2 2,2'-Azinobis-3-ethylbenzthiazoline-6-sulfonic acid $\left(\right.$ ABTS $\left.^{\cdot+}\right)$ scavenging assay. The scavenging activity of $\mathrm{ABTS}^{\cdot+}$ was conducted to measure the radical scavenger activity. ${ }^{39}$ The radical scavenging capacity of the samples for the ABTS $\left(2,2^{\prime}\right.$ azinobis-3-ethylbenzothiazoline-6-sulfonate) radical cation was determined as described previously. ${ }^{\mathbf{4 0 , 4 1}}$ ABTS was generated by mixing $7 \mathrm{mM}$ of ABTS and $140 \mathrm{mM}$ of $\mathrm{K}_{2} \mathrm{~S}_{2} \mathrm{O}_{8}$ (potassium persulfate) and stored in the dark at room temperature for $16 \mathrm{~h}$ before use. The mixture was diluted $(1: 80)$ with ethanol to achieve absorbance at $734 \mathrm{~nm}$ using the spectrophotometer. The sample with different concentrations $(0.015,0.020,0.025$, $0.030,0.035$ and $0.040 \mathrm{mg} \mathrm{mL}^{-1}$ ) was diluted with $100 \mu \mathrm{L}$ of the required amount to react with the fresh ABTS solution $(900 \mu \mathrm{L})$. Then, the absorbance was measured 6 min after initial mixing. All measurements were performed in triplicate.

The inhibition of ABTS by the samples was defined as:

$$
\begin{aligned}
& \text { ABTS radical scavenging activity }= \\
& \left(\frac{A_{734} \text { blank }-A_{734} \text { sample }}{A_{734} \text { blank }}\right) \times 100 \%,
\end{aligned}
$$

where $A_{734}$ indicates the absorbance measured at $734 \mathrm{~nm}$.

2.2.4 Cell culture. The Caco-2 cells (CBCAS, Shanghai, China) were maintained in MEM (Hyclone Laboratories, Inc., USA) and supplemented with 10\% FBS (Gibco BRL Co., Ltd., USA), penicillin (100 kU L $\left.{ }^{-1}\right)$, and streptomycin $\left(100 \mathrm{~g} \mathrm{~L}^{-1}\right)$ at $37{ }^{\circ} \mathrm{C}$ in a $5 \% \mathrm{CO}_{2}$ atmosphere in a humidified incubator. ${ }^{42,43}$ After reaching $70-80 \%$ confluence, the cells were sub-cultured and maintained with medium changes every 1-2 days.

2.2.5 Cell morphology. For the document morphological changes in Caco-2 cells in response to the different concentrations of C3G liposomes, the cells (control and C3G liposomes exposed) were washed with PBS after $12 \mathrm{~h}$ of incubation. The phase contrast images of the cells exposed to the C3G liposomes were obtained using an inverted microscope (Nikon Eclipse Ti, Nikon, Shinjuku, Tokyo, Japan) at $200 \times$ magnification. $^{\mathbf{4 4}}$

2.2.6 Microscopic assessment of Caco-2 cells. To observe the changes of organelle in Caco-2 cells in response to $\mathrm{C} 3 \mathrm{G}$ liposomes, the cells (control and C3G liposomes exposed) were washed with PBS after $12 \mathrm{~h}$ of incubation, harvested with trypsin-EDTA solution, and centrifuged at $1000 \mathrm{rpm}$ for $5 \mathrm{~min}$. Then, the specimen was fixed with $2.5 \%$ glutaraldehyde in phosphate buffer ( $\mathrm{pH}$ 7.0) for $12 \mathrm{~h}$, washed three times in the phosphate buffer, post-fixed with $1 \% \mathrm{OsO}_{4}$ in the phosphate buffer ( $\mathrm{pH}$ 7.0) for $1 \mathrm{~h}$, and washed three times with phosphate buffer. The specimen was dehydrated by a graded series of ethanol $(30 \%, 50 \%, 70 \%, 80 \%, 90 \%, 95 \%$, and $100 \%)$ for $15 \mathrm{~min}$ at each step, transferred to absolute acetone for $20 \mathrm{~min}$, placed in a 1:1 mixture of absolute acetone and final Spurr resin mixture for $1 \mathrm{~h}$ at room temperature, transferred to a $1: 3$ 
mixture of absolute acetone and final resin mixture for $3 \mathrm{~h}$, and then to the final Spurr resin mixture overnight. The specimen was placed in capsules containing the embedding medium and heated at $70{ }^{\circ} \mathrm{C}$ for about $9 \mathrm{~h}$. The specimen sections were stained by uranyl acetate and alkaline lead citrate for $15 \mathrm{~min}$ and observed under a TEM (JEM-2100, Japanese Electronics Co., Ltd., Tokyo, Japan).

2.2.7 Cell proliferation. Cell proliferation was tested by the CCK-8 assay (Beyotime, Shanghai, China). The Caco-2 cells were prepared and dispersed in 96-well cell culture plates at a cellular density of $1.0 \times 10^{5}$ cells per well. After incubating with different concentrations of C3G and C3G liposomes for $24 \mathrm{~h}, 10$ $\mu \mathrm{L}$ of CCK-8 solution in PBS was added to each well and incubated at $37{ }^{\circ} \mathrm{C}$ for $2 \mathrm{~h}$. The results were calculated as the absorbance of the treated cells relative to the untreated controls. Cell proliferation was assessed by a microplate reader at a wavelength of $450 \mathrm{~nm}^{45}$

2.2.8 Apoptosis measurement with FCM. Cell apoptosis was measured using the Annexin V-FITC/PI apoptosis detection kit (Solarbio Life Sciences, Beijing, China). The cells were seeded into 6-well plates at a density of $1 \times 10^{5}$ cells per $\mathrm{mL}$ per well. After exposure to the indicated concentrations of $\mathrm{C} 3 \mathrm{G}$ and C3G liposomes for $12 \mathrm{~h}$, the cells were harvested, washed with PBS, and then resuspended in $400 \mu \mathrm{L}$ of binding buffer. Finally, the cells were stained with $5 \mu \mathrm{L}$ of Annexin V and $5 \mu \mathrm{L}$ of PI in the dark for $15 \mathrm{~min}$ at room temperature. All samples were then analyzed using a flow cytometer. ${ }^{46}$ The apoptosis rates at each concentration were recorded.

2.2.9 Statistical analysis. All experiments were performed thrice per sample. The results were presented as means \pm standard deviations from at least three independent measurements. Statistical analysis was performed using SPSS version 21.0 for Windows (International Business Machines Corporation, Armonk, NY, USA).

\section{Results and discussion}

\subsection{Characterization studies}

Fig. 1 shows that the size distribution curve of the C3G liposomes was a normalized curve that reveals the size variation among particles. Meanwhile, Fig. 2 shows a representative TEM image of the C3G liposomes. The nanoparticles exhibited spherical shapes, and the size of the C3G liposomes was approximately $200 \mathrm{~nm}$, from our previous study, ${ }^{34}$ the average diameter and polydispersity of C3G liposomes is $165.78 \pm$ $4.3 \mathrm{~nm}$ and $0.143 \pm 0.025$, the encapsulation efficiency of C3G liposomes is $70.43 \% \pm 1.95 \%$.

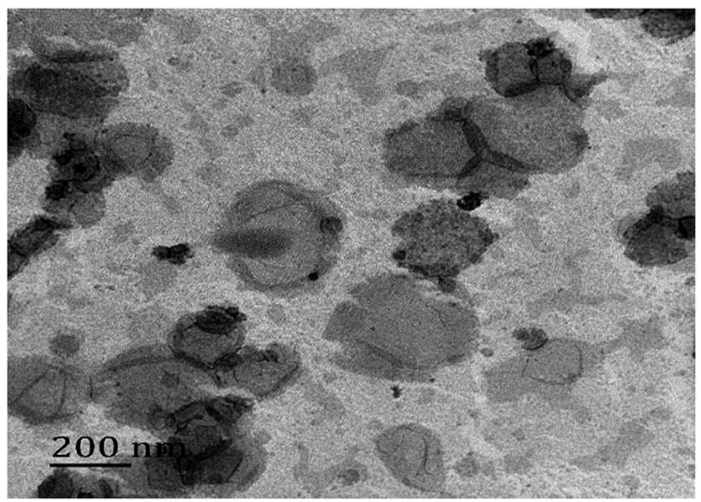

Fig. 2 Microscopy characterizations of C3G liposomes. Transmission Election Microscope (TEM) image of C3G liposomes.

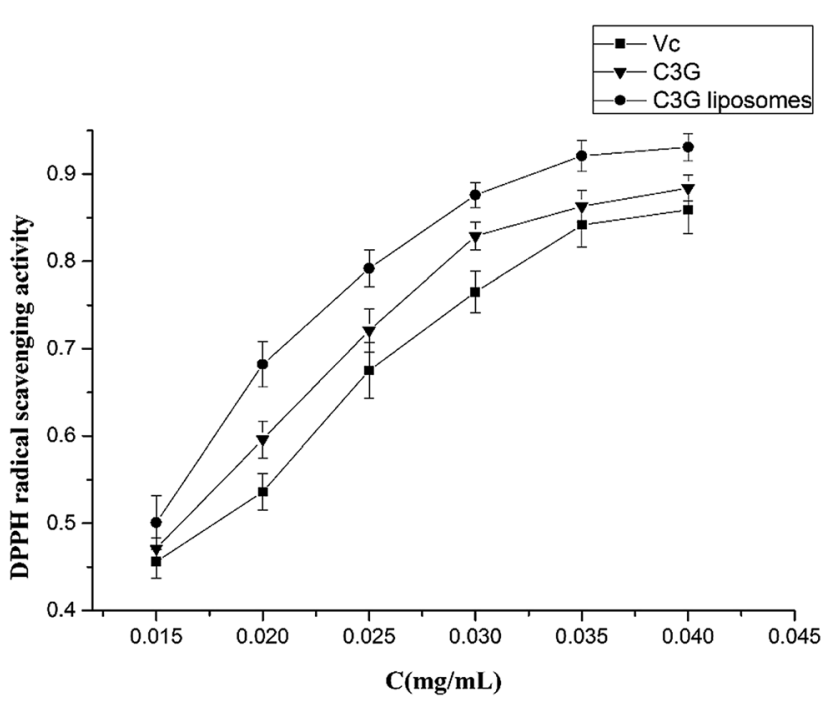

Fig. 3 Comparative analysis of DPPH radical scavenging activity of C3G liposomes, C3G and Vc.

Size Distribution by Volume

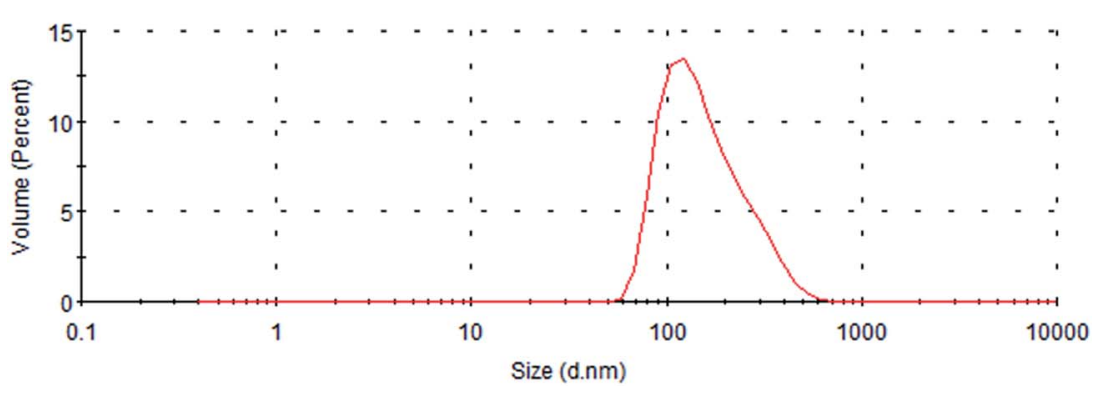

Fig. 1 The particle size of C3G liposomes. 


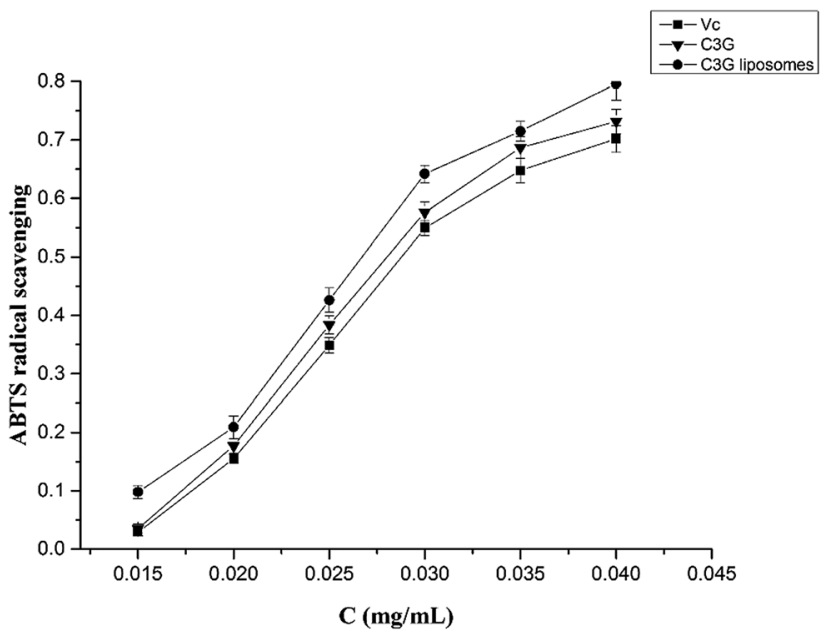

Fig. 4 Comparison of $\mathrm{ABTS}^{*+}$ radicals scavenging activity between C3G liposomes, C3G and VC.

\subsection{Antioxidant assay}

3.2.1 DPPH $^{`}$ radical scavenging activity. Several chemical assays have been established to evaluate the antioxidant activities of plants by measuring their oxidation/reduction potentials. ${ }^{47}$ However, DPPH assay is the most authoritative method and thus employed in this study to compare the antioxidant activities of C3G liposomes, C3G, and vitamin C (Vc). In the $\mathrm{DPPH}$ radical scavenging assay, the variable concentrations $\left(0.015,0.020,0.025,0.030,0.035\right.$, and $\left.0.040 \mathrm{mg} \mathrm{mL}^{-1}\right)$ of the samples showed dose-dependent inhibition percentages. The results of the antioxidant activity assays using DPPH (expressed as TEAC and VCEAC) are presented in Fig. 3. As shown in Fig. 3, the scavenging abilities increased with the increasing sample concentration. The Vc group was the general control group. C3G and C3G liposomes showed strong DPPH radical scavenging abilities. The scavenging rate of C3G liposomes reached $90.8 \%$ $\pm 0.016 \%$ at $0.04 \mathrm{mg} \mathrm{mL}^{-1}$, which was $7.7 \%$ higher than that of C3G $(88.7 \% \pm 0.015 \%)$. Vc showed a $75.6 \% \mathrm{DPPH}^{\circ}$ radical scavenging ability at $0.04 \mathrm{mg} \mathrm{mL}^{-1}$. The $\mathrm{IC}_{50}$ values for the $\mathrm{DPPH}^{*}$ radical scavenging activities of $\mathrm{C} 3 \mathrm{G}$ liposomes, $\mathrm{C} 3 \mathrm{G}$, and Vc were $0.011,0.014$, and $0.016 \mathrm{mg} \mathrm{mL}^{-1}$, respectively. The reducing power of the samples followed the order: C3G liposomes $>$ C3G $>$ Vc. C3G liposomes exhibited the highest antioxidant activity.

3.2.2 ABTS $^{++}$scavenging assay. ABTS assay is the most common, easiest, and simplest method for estimating the scavenging ability of free radicals (free radical scavenging ability).$^{48}$ The radical $\mathrm{ABTS}^{+}{ }^{\cdot}$ was reduced by the antioxidants in the sample (either by electron transfer or by hydrogen atom transfer) and deactivated. In the ABTS assay, the variable concentrations $(0.015,0.020,0.025,0.030,0.035$, and $0.040 \mathrm{mg}$ $\mathrm{mL}^{-1}$ ) of the samples showed dose-dependent inhibition percentages as illustrated in Fig. 4. C3G liposomes with concentrations of $0.015,0.020,0.025,0.030,0.035$, and $0.040 \mathrm{mg} \mathrm{mL}^{-1}$ extracts exhibited $\mathrm{ABTS}^{{ }^{+}}$radical scavenging rates of $0.035 \pm 0.008,0.177 \pm 0.012,0.384 \pm 0.016,0.486 \pm$ $0.018,0.598 \pm 0.019$, and $0.732 \pm 0.021$, respectively. Meanwhile, the ABTS radicals scavenging rates of $\mathrm{C} 3 \mathrm{G}$ at the same concentrations were $0.098 \pm 0.011,0.209 \pm 0.019,0.426 \pm$ $0.021,0.529 \pm 0.015,0.685 \pm 0.017$, and $0.781 \pm 0.028$, respectively. These results indicated that $\mathrm{C} 3 \mathrm{G}$ liposomes could act as electron donors, react with free radicals, convert them into more stable products, and terminate the radical chain reactions. The ABTS radical scavenging rates of C3G liposomes were higher than those of $\mathrm{C} 3 \mathrm{G}$ at concentrations more than $0.03 \mathrm{mg} \mathrm{mL}^{-1}$. Hence, liposomes protected the $\mathrm{C} 3 \mathrm{G}$ from the influence of the external environment.

\subsection{Anticancer activity}

3.3.1 Cell morphology. The Caco- 2 cells were treated with $0,0.05,0.10,0.15,0.20$, and $0.25 \mathrm{mg} \mathrm{mL}^{-1}$ of $\mathrm{C} 3 \mathrm{G}$ and $\mathrm{C} 3 \mathrm{G}$ liposomes for $12 \mathrm{~h}$ and washed with PBS three times. Then, the

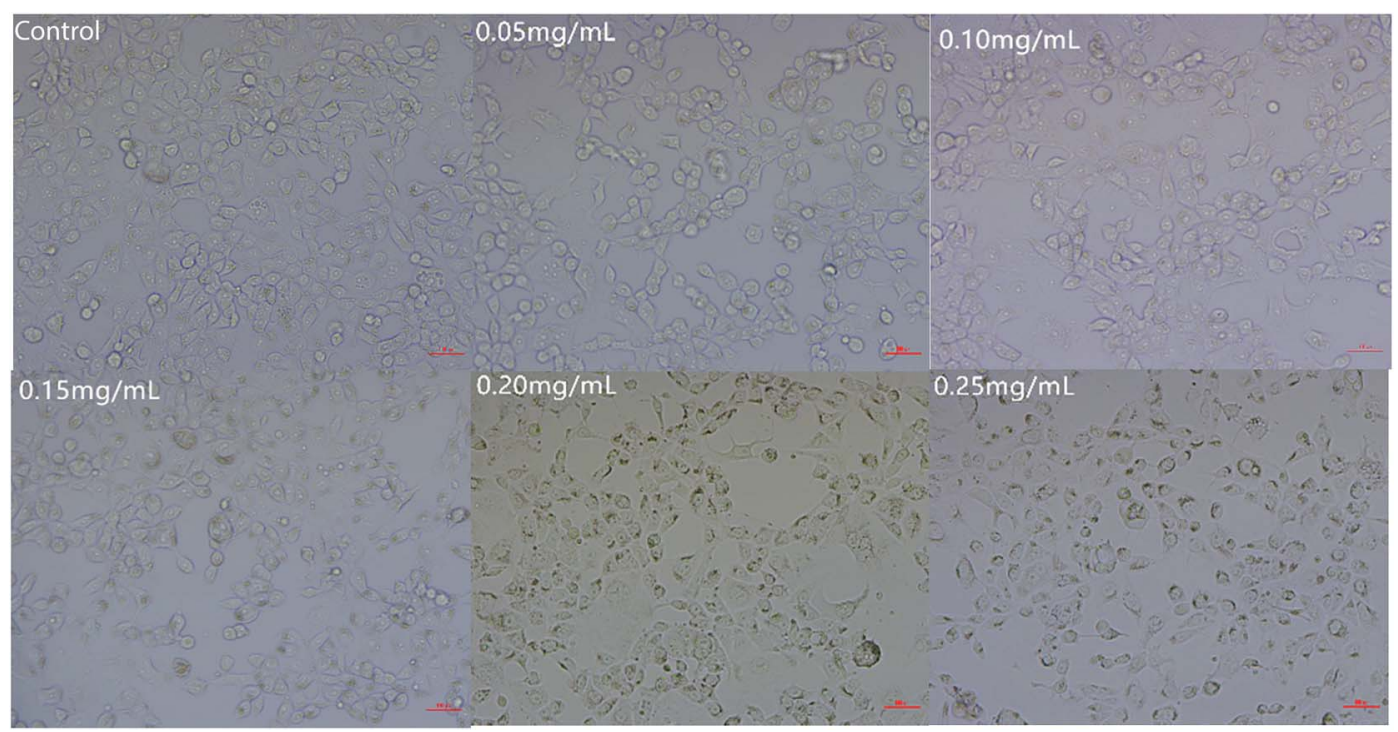

Fig. 5 Cell morphology of Caco-2 cells treated with different concentrations of C3G liposomes. 


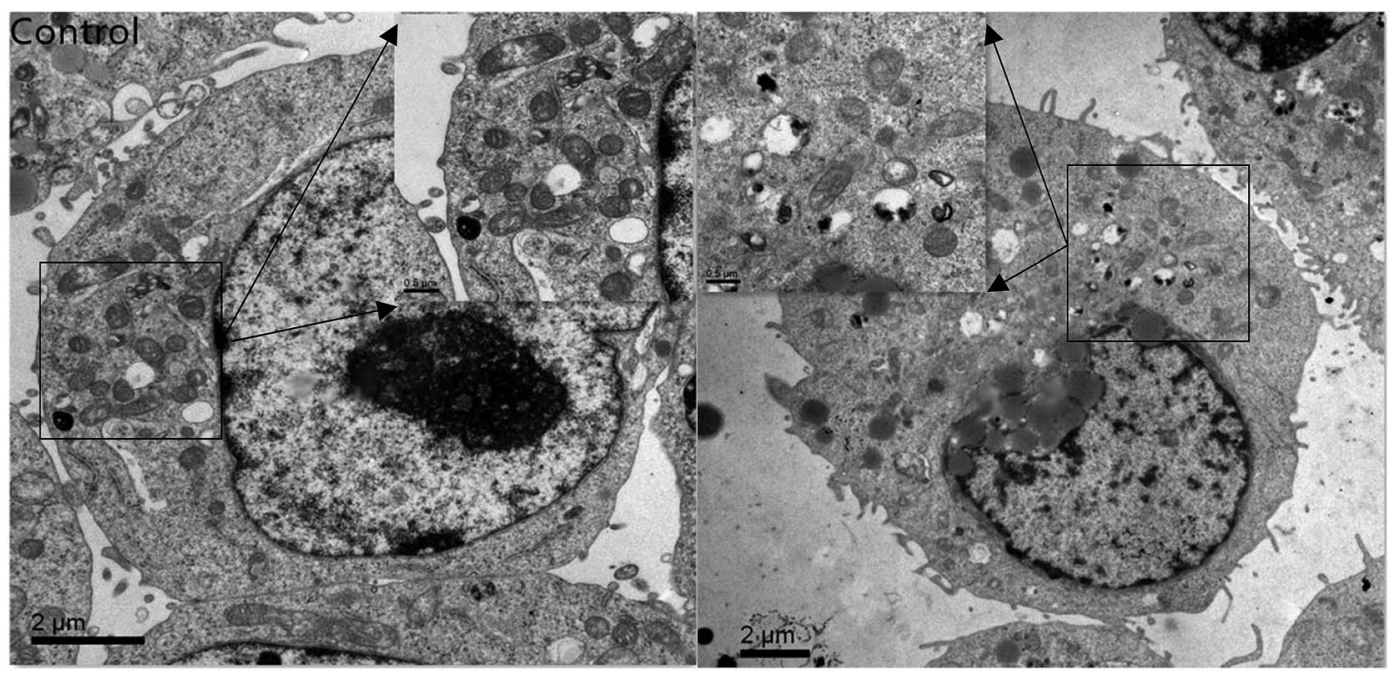

Fig. 6 Transmission electron microscope images of Caco-2 cells treated with C3G liposomes for $12 \mathrm{~h}$.

cell morphology was observed at $200 \times$ magnification using an inverted microscope.

As shown in Fig. 5, the number of cells decreased as the concentration of C3G liposomes increased. The morphology of the cells became spherical as the number of cells decreased, which showed that C3G liposomes affected the morphology of Caco-2 cells. Compared to the control, the cells cultivated with low doses of C3G liposomes $\left(0.05 \mathrm{mg} \mathrm{mL}^{-1}\right)$ were similar in appearance with the control cells and had brownish particles that were most likely associated with the cell membranes. This result indicated that the cells were unaffected by lower doses of C3G liposomes. The cells began to shrink and became irregularly shaped as the concentration of the C3G liposomes increased. When the concentration of C3G liposomes reached $0.20 \mathrm{mg} \mathrm{mL}^{-1}$, the number of cells decreased and apoptosis and necrosis were observed. Microscopic studies indicated that the cells exposed to C3G liposomes at higher doses became abnormal in size, acquired an irregular shape, and displayed cellular shrinkage. This cell morphology study indicated that C3G liposomes could inhibit proliferation and induce the apoptosis of Caco-2 cells.

3.3.2 Microscopic assessment of Caco-2 cells. The Caco-2 cells were treated with C3G liposomes for $12 \mathrm{~h}$, and the cells cultured in the free medium were taken as the control. The images of the cells (control and C3G liposomes exposed) are shown in Fig. 6. As presented in Fig. 6, the cells treated with C3G liposomes exhibited changes in several organelles. First, the number of fat droplet increased after being treated with C3G liposomes, indicating that C3G liposomes could affect the number of fat droplet. Second, the number and morphology of mitochondria that had some changes were treated with C3G liposomes. Compared to the control, the number of mitochondria decreased, and the structure of the mitochondria changed after being treated with liposomes. Fig. 6 shows that some swollen mitochondria appeared, and the structure of mitochondria changed. The ridge of mitochondria disappeared with the liposome treatment. Third, a few physalides appeared in the treated cells. In summary, the microscopic structure of cells exhibited some changes with the treatment of C3G liposomes. In addition, the changes in the numbers and structures of mitochondria and fat droplet led to the appearance of physalides, thereby indicating that C3G liposomes had an effect on the microscopic structure of cells and the mechanism of the changes of these organelles needs further study.

3.3.3 Cell proliferation. The Caco-2 cells were exposed to C3G and C3G liposomes $\left(0-0.25 \mathrm{mg} \mathrm{mL}^{-1}\right)$ for $24 \mathrm{~h}$, and their activity was monitored by the CCK- 8 assay.

The CCK-8 assay results demonstrated a concentrationdependent activity after exposure to C3G and C3G liposomes (Fig. 7). CCK-8 assay was used to compare cell proliferation at different concentrations of C3G and C3G liposomes. The lowest and the highest cell proliferations were observed in cells treated with C3G and C3G liposomes, respectively. At the end of the $24 \mathrm{~h}$ growth study, the cell proliferation in cells exposed to C3G liposomes was $42.8 \%$ lower than that on $\mathrm{C} 3 \mathrm{G}$ at $0.20 \mathrm{mg} \mathrm{mL}^{-1}$

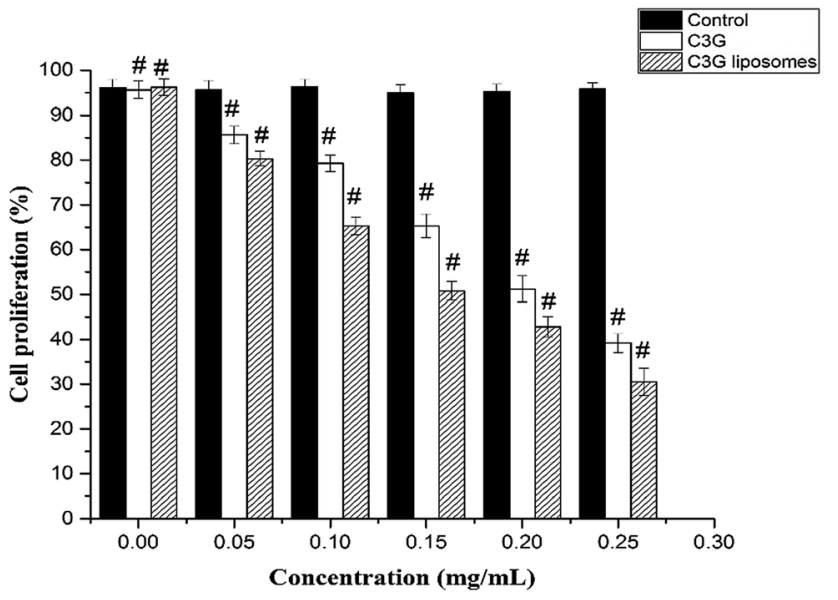

Fig. 7 Cell proliferation of Caco-2 cells treated with different concentrations of C3G and C3G liposomes at $12 \mathrm{~h}$ (data reported are mean values \pm standard variation of three replications) $(\# p<0.05$, compared with the ctrl group). 

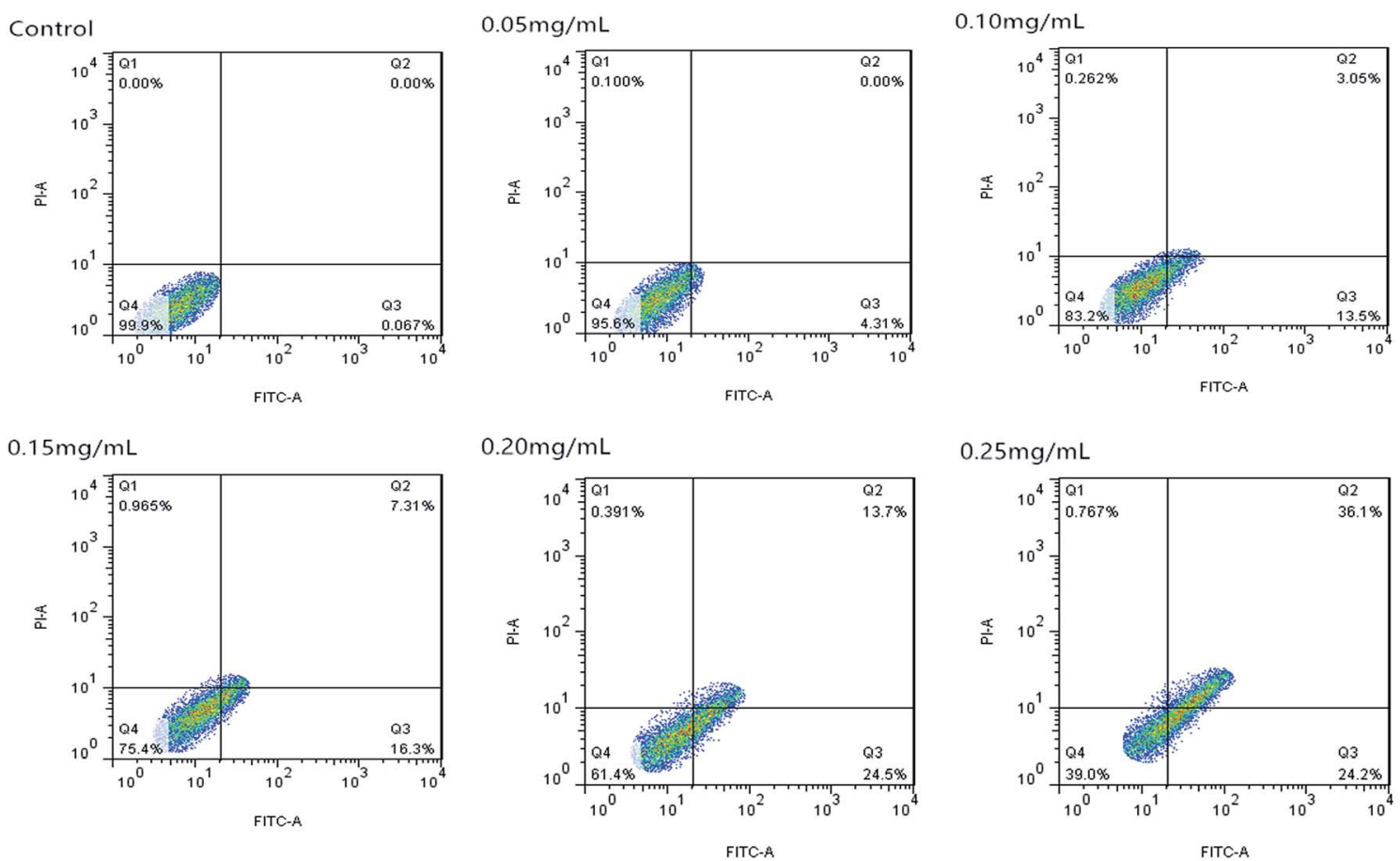

Fig. 8 Apoptosis of Caco-2 cells induced by C3G liposomes detected by flow cytometry analysis.

(Fig. 7) as the cell proliferation is $51.2 \%$ when cells exposed to C3G. The result demonstrated that C3G liposomes significantly inhibited tumor cell proliferation compared to C3G. The mechanism for increasing or improving the bioactivity of C3G liposomes needs to be investigated further.
3.3.4 Apoptosis measurement with flow cytometry analysis. The Caco-2 cells were treated with different concentrations of C3G and C3G liposomes for $12 \mathrm{~h}$. Cell apoptosis was measured using the Annexin V-FITC/PI apoptosis detection kit. The results

\section{Control}

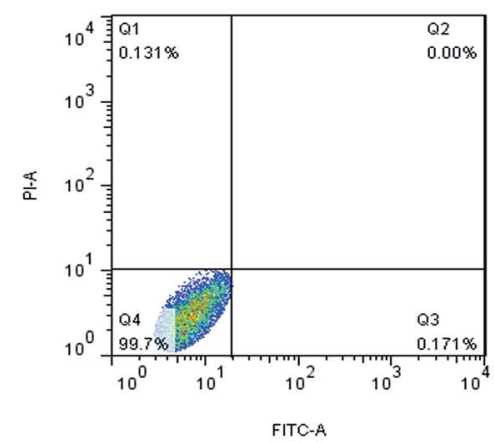

$0.15 \mathrm{mg} / \mathrm{mL}$

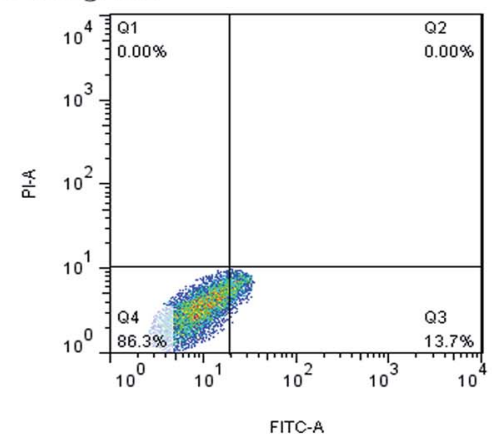

$0.05 \mathrm{mg} / \mathrm{mL}$

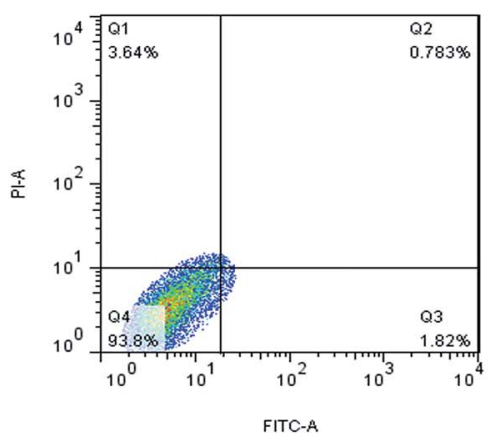

$0.20 \mathrm{mg} / \mathrm{mL}$

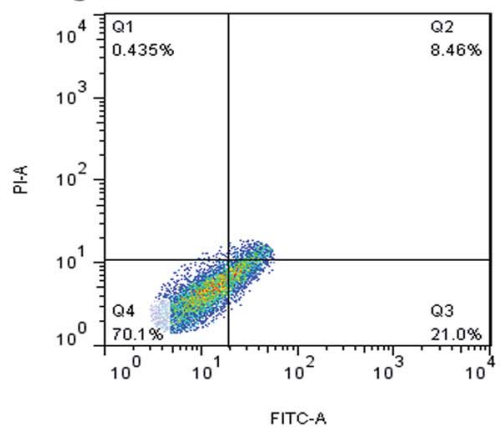

$0.10 \mathrm{mg} / \mathrm{mL}$

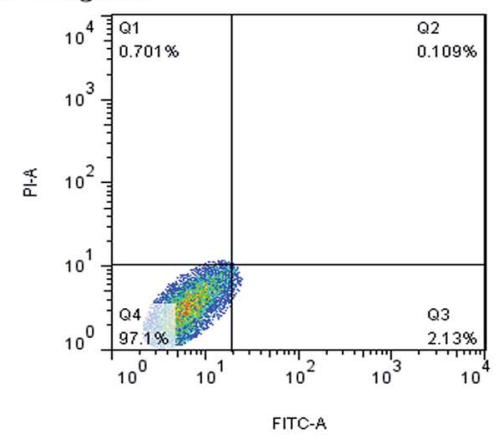

$0.25 \mathrm{mg} / \mathrm{mL}$

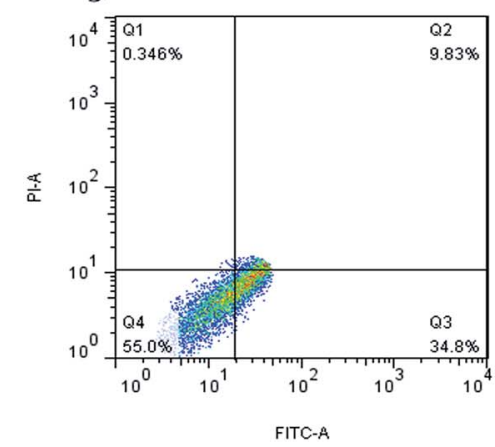

Fig. 9 Apoptosis of Caco-2 cells induced by C3G detected by flow cytometry analysis. 


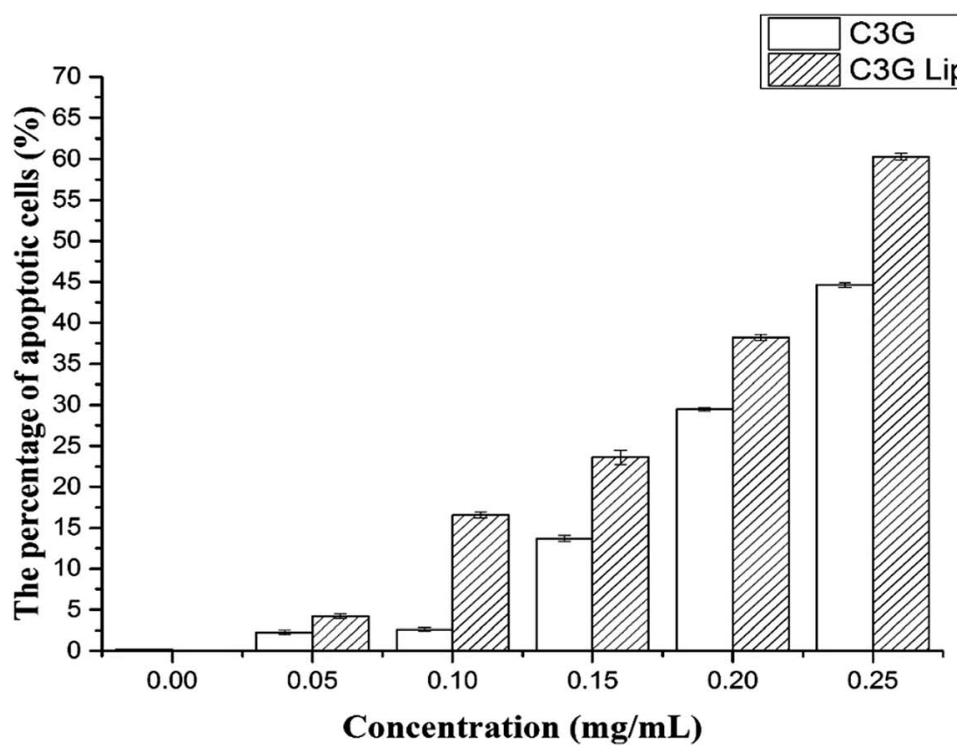

Fig. 10 The cell apoptosis rates of Caco-2 cells treated with different concentrations of C3G and C3G liposomes for $12 \mathrm{~h}$.

are shown in Fig. 8 and 9, and the percentage of apoptotic cells is shown in Fig. 10.

Fig. 10 shows that the cell apoptosis rates in different concentration groups significantly increased compared with those in the control group. The cell apoptosis rates (relative to control) observed after C3G liposome exposure at $12 \mathrm{~h}$ with 0 , $0.05,0.10,0.15,0.20$, and $0.25 \mathrm{mg} \mathrm{mL}^{-1}$ concentrations were $0.067 \%, 4.21 \%, 16.55 \%, 23.61 \%, 38.2 \%$, and $60.3 \%$, while the cell apoptosis rates (relative to control) observed after C3G exposure at $12 \mathrm{~h}$ with $0,0.05,0.10,0.15,0.20$, and $0.25 \mathrm{mg} \mathrm{mL}^{-1}$ concentrations were $0.171 \%, 2.239 \%, 2.603 \%, 13.7 \%, 29.46 \%$ and $44.63 \%$. Compared with C3G, the C3G liposomes can induce the higher cell apoptosis rates at different concentrations.

The FCM results showed that compare with $\mathrm{C} 3 \mathrm{G}$, the $\mathrm{C} 3 \mathrm{G}$ liposomes could significantly induce $(p<0.05)$ cell apoptosis in Caco-2 cells.

\section{Discussion}

We compared the antioxidant and anticancer activities of C3G and C3G liposomes and studied their effect on the Caco- 2 cells in this study. Results showed that the liposomes protected the C3G from the influence of the external environment. In addition, C3G liposomes could inhibit proliferation, affect the microscome structure, and induce the apoptosis of Caco- 2 cells.

C3G is a potent antioxidant that displays anticancer properties in vitro and in vivo. ${ }^{\mathbf{1 1 , 4 9 , 5 0}}$ However, few studies have evaluated the antioxidant and anticancer properties of $\mathrm{C} 3 \mathrm{G}$ liposomes. The results of this study revealed that C3G liposomes inhibited cell proliferation and affected cell morphology and structure in certain concentrations. However, this work did not focus on the molecular level of C3G liposomes to study their properties and effects on Caco-2 cells. Several studies have investigated the effect of $\mathrm{C} 3 \mathrm{G}$ on cells at the molecular level. We think is worthwhile to study the effect of C3G liposomes on cells at the molecular level.
In this study, we have investigated the effect of C3G liposomes on cells, not nanoliposomes. In the future studies, we will use the C3G nanoliposomes to culture cell to study the effect of nanoliposomes to cells in molecular level, so a smaller size of C3G nanoliposomes is expected, and because the liposomes were used as carriers, the size is smaller, and they are more effective. At the same time, the uniform particle size can improve the stability of liposomes, a new method for preparation nanoliposomes is important in our further study.

Therefore, we will use a new cell culture model to investigated the mechanisms of the anticancer and antioxidant activities with $\mathrm{C} 3 \mathrm{G}$ nanoliposomes at the molecular level in future study. At the same time, the properties, expression of specific genes and proteins, effects and mechanisms of C3G liposomes on cancer cells will explored in the further study.

\section{Conclusion}

The antioxidant and anticancer activities of C3G and C3G liposomes were studied in this work. The ABTS and DPPH assay results showed that $\mathrm{C} 3 \mathrm{G}$ liposomes processed the highest antioxidant activity compared with $\mathrm{C} 3 \mathrm{G}$ and Vc, indicating that liposomes protected $\mathrm{C} 3 \mathrm{G}$ from the influence of the external environment. The anticancer activity results showed that C3G liposomes could inhibit proliferation and induce apoptosis of the Caco- 2 cells. The microscopic assessment of Caco- 2 cells showed that C3G liposomes affect the microscopic structure of Caco-2 cells. The FCM results showed that C3G liposomes could significantly induce $(p<0.05)$ cell apoptosis in Caco- 2 cells in a dosedependent manner.

\section{Conflict of interest}

The author(s) declare(s) that they have no conflicts of interest to disclose. 


\section{Abbreviations}

$\begin{array}{ll}\text { C3G } & \text { Cyanidin-3-O-glucoside } \\ \text { Caco-2 cells } & \text { Human epithelial colorectal adenocarcinoma cells } \\ \text { MEM } & \text { Minimum essential medium } \\ \text { FBS } & \text { Fetal bovine serum } \\ \text { PC } & \text { Phosphatidylcholine } \\ \text { CH } & \text { Cholesterol } \\ \text { TEM } & \text { Transmission electron microscope } \\ \text { DPPH } & \text { 2,2-Diphenyl-1-picrylhydrazyl } \\ \text { ABTS } & \text { 2,2'-Azinobis-3-ethylbenzthiazoline-6-sulfonic } \\ & \text { acid } \\ \text { FCM } & \text { Flow cytometry }\end{array}$

\section{Acknowledgements}

This work was supported by Zhejiang Provincial Key Laboratory of Biometrology and Inspection and Quarantine, and National \& Local United Engineering Lab of Quality Controlling Technology and Instrumentation for Marine Food. We gratefully acknowledge financial support from National Natural Science Foundation of China (31571845), the national key research and development plan during the 13th five-year plan period (2016YED0401503) and General Administration of Quality Supervision, Inspection and Quarantine of the People's Republic of China (201410083).

\section{References}

1 H. Jung, H.-K. Kwak and K. T. Hwang, Antioxidant and antiinflammatory activities of cyanidin-3-glucoside and cyanidin-3-rutinoside in hydrogen peroxide and lipopolysaccharide-treated RAW264.7 cells, Food Sci. Biotechnol., 2014, 23(6), 2053-2062.

2 M.-M. Ma, Y. Li, X.-Y. Liu, W.-W. Zhu, X. Ren, G.-Q. Kong, et al., Cyanidin-3-O-Glucoside Ameliorates Lipopolysaccharide-Induced Injury Both In Vivo and In Vitro Suppression of NF- $\kappa \mathrm{B}$ and MAPK Pathways, Inflammation, 2015, 38(4), 1669-1682.

3 H. Cai, B. Yang, Z. Xu, B. Zhang, B. Xu, X. Li, et al., Cyanidin3-O-Glucoside Enhanced the Function of Syngeneic Mouse Islets Transplanted Under the Kidney Capsule or Into the Portal Vein, Transplantation, 2015, 99(3), 508-514.

4 C. Scarfiotti, F. Fabris, B. Cestaro and A. Giuliani, Free radicals, atherosclerosis, ageing, and related dysmetabolic pathologies: pathological and clinical aspects, Eur. J. Cancer Prev., 1997, 6(2), S31-S6.

5 E. Kowalczyk, P. Krzesiński, P. Fijałkowski, J. Błaszczyk and J. Kowalski, The use of anthocyanins in the treatment of cardiovascular diseases, Pol. Merkuriusz Lek., 2005, 19(109), 108.

6 L. Yi, C.-Y. Chen, X. Jin, M.-T. Mi, B. Yu, H. Chang, et al., Structural requirements of anthocyanins in relation to inhibition of endothelial injury induced by oxidized lowdensity lipoprotein and correlation with radical scavenging activity, FEBS Lett., 2010, 584(3), 583-590.
7 M. Kyraleou, S. Koundouras, S. Kallithraka, N. Theodorou, N. Proxenia and Y. Kotseridis, Effect of irrigation regime on anthocyanin content and antioxidant activity of Vitis vinifera L. cv. Syrah grapes under semiarid conditions, $J$. Sci. Food Agric., 2016, 96(3), 988-996.

8 E. O. Cuevas Rodriguez, V. P. Dia, G. G. Yousef, P. A. GarciaSaucedo, et al., Inhibition of pro-inflammatory responses and antioxidant capacity of Mexican blackberry (Rubus spp.) extracts, J. Agric. Food Chem., 2010, 58(17), 9542-9548.

9 D. Ferrari, F. Cimino, D. Fratantonio, M. S. Molonia, R. Bashllari, R. Busa, et al., Cyanidin-3-O-Glucoside Modulates the In Vitro Inflammatory Crosstalk between Intestinal Epithelial and Endothelial Cells, Mediators Inflammation, 2017, 2017, 3454023.

10 P. Pratheeshkumar, Y. O. Son, X. Wang, S. P. Divya, B. Joseph, J. A. Hitron, et al., Cyanidin-3-glucoside inhibits UVB-induced oxidative damage and inflammation by regulating MAP kinase and NF-kappaB signaling pathways in SKH-1 hairless mice skin, Toxicol. Appl. Pharmacol., 2014, 280(1), 127-137.

11 P. H. Shih, C. T. Yeh and G. C. Yen, Effects of anthocyanidin on the inhibition of proliferation and induction of apoptosis in human gastric adenocarcinoma cells, Food Chem. Toxicol., 2005, 43(10), 1557-1566.

12 J. S. Lee, Y. R. Kim, J. M. Park, Y. E. Kim, N. I. Baek and E. K. Hong, Cyanidin-3-glucoside isolated from mulberry fruits protects pancreatic beta-cells against glucotoxicityinduced apoptosis, Mol. Med. Rep., 2015, 11(4), 2723-2728.

13 X. Yan, L. Wu, B. Li, X. Meng, H. Dai, Y. Zheng, et al., Cyanidin-3-O-glucoside Induces Apoptosis and Inhibits Migration of Tumor Necrosis Factor- $\alpha$-Treated Rat Aortic Smooth Muscle Cells, Cardiovasc. Toxicol., 2016, 16(3), 251-259.

14 D. Liu, F. Pan, J. Liu, Y. Wang, T. Zhang, E. Wang, et al., Individual and combined antioxidant effects of ginsenoside $\mathrm{F} 2$ and cyanidin-3-O-glucoside in human embryonic kidney 293 cells, RSC Adv., 2016, 6(84), 8109281100.

15 X. Yan, L. Wu, B. Li, X. Meng, H. Dai, Y. Zheng, et al., Cyanidin-3-O-glucoside Induces Apoptosis and Inhibits Migration of Tumor Necrosis Factor-alpha-Treated Rat Aortic Smooth Muscle Cells, Cardiovasc. Toxicol., 2015, 251-259.

16 N. Priego, M. Arechederra, C. Sequera, P. Bragado, A. Vázquezcarballo, Á. Gutiérrezuzquiza, et al., C3G knockdown enhances migration and invasion by increasing Rap1-mediated p38 $\alpha$ activation, while it impairs tumor growth through p38 $\alpha$-independent mechanisms, OncoTargets Ther., 2016, 7(29), 45060-45078.

17 D. Fratantonio, F. Cimino, M. S. Molonia, D. Ferrari, A. Saija, F. Virgili, et al., Cyanidin-3-O-glucoside ameliorates palmitate-induced insulin resistance by modulating IRS-1 phosphorylation and release of endothelial derived vasoactive factors, Biochim. Biophys. Acta, 2017, 1862(3), 351-357.

18 S. Sivasinprasasn, R. Pantan, S. Thummayot, J. Tocharus, A. Suksamrarn and C. Tocharus, Cyanidin-3-glucoside 
attenuates angiotensin II-induced oxidative stress and inflammation in vascular endothelial cells, Chem.-Biol. Interact., 2016, 260, 67-74.

19 A. D. Bangham, M. W. Hill and N. G. A. Miller, Preparation and Use of Liposomes as Models of Biological Membranes, in Methods in Membrane Biology, ed. E. D. Korn, Springer US, Boston, MA, 1974, vol. 1, pp. 1-68.

20 R. Guan, J. Ma, Y. Wu, F. Lu, C. Xiao, H. Jiang, et al., Development and characterization of lactoferrin nanoliposome: cellular uptake and stability, Nanoscale Res. Lett., 2012, 7(1), 679.

21 M. Guan, Y. Zhou, Q.-L. Zhu, Y. Liu, Y.-Y. Bei, X.-N. Zhang, et al., $N$-Trimethyl chitosan nanoparticle-encapsulated lactosyl-norcantharidin for liver cancer therapy with high targeting efficacy, Nanomedicine, 2012, 8(7), 1172-1181.

22 L. Zou, S. Peng, W. Liu, X. Chen and C. Liu, A novel delivery system dextran sulfate coated amphiphilic chitosan derivatives-based nanoliposome: capacity to improve in vitro digestion stability of (-)-epigallocatechin gallate, Food Res. Int., 2015, 69, 114-120.

23 Y.-W. Noh, S.-Y. Kim, J.-E. Kim, S. Kim, J. Ryu, I. Kim, et al., Multifaceted Immunomodulatory Nanoliposomes: Reshaping Tumors into Vaccines for Enhanced Cancer Immunotherapy, Adv. Funct. Mater., 2017, 27(8), 1605398.

24 C. Cheng, S. Peng, Z. Li, L. Zou, W. Liu and C. Liu, Improved bioavailability of curcumin in liposomes prepared using a pH-driven, organic solvent-free, easily scalable process, RSC Adv., 2017, 7(42), 25978-25986.

25 J. Tian, M. Han, Y. Wang, K. Qian, X. Ke and T. Ci, Reduction-responsive modification-induced higher efficiency for attenuation of tumor metastasis of low molecular weight heparin functionalized liposomes, RSC Adv., 2016, 6(54), 49250-49262.

26 K. M. Hosny and H. M. Aldawsari, Avanafil Liposomes as Transdermal Drug Delivery for Erectile Dysfunction Treatment: Preparation, Characterization, and In Vitro, Ex Vivo and In Vivo Studies, Trop. J. Pharm. Res., 2015, 14(4), 559.

27 S. Bochicchio, A. A. Barba, G. Grassi and G. Lamberti, Vitamin delivery: carriers based on nanoliposomes produced via ultrasonic irradiation, LWT-Food Sci. Technol., 2016, 69, 9-16.

28 Y. Liu, D. Gao, X. Zhang, Z. Liu, K. Dai, B. Ji, et al., Antitumor drug effect of betulinic acid mediated by polyethylene glycol modified liposomes, Mater. Sci. Eng., C, 2016, 64, 124-132.

29 K. Tahara, H. Tomida, Y. Ito, S. Tachikawa, R. Onodera, H. Tanaka, et al., Pulmonary liposomal formulations encapsulated procaterol hydrochloride by a remote loading method achieve sustained release and extended pharmacological effects, Int. J. Pharm., 2016, 505(1-2), 139146.

30 Z. Rafiee, M. Barzegar, M. A. Sahari and B. Maherani, Nanoliposomal carriers for improvement the bioavailability of high - valued phenolic compounds of pistachio green hull extract, Food Chem., 2017, 220, 115-122.

31 S. Jung, S. Lee, H. Lee, J. Yoon and E. K. Lee, Oleic acidembedded nanoliposome as a selective tumoricidal agent, Colloids Surf., B, 2016, 146, 585-589.
32 T. Ghorbanzade, S. M. Jafari, S. Akhavan and R. Hadavi, Nano-encapsulation of fish oil in nano-liposomes and its application in fortification of yogurt, Food Chem., 2017, 216, 146-152.

33 X. Luo, R. Guan, X. Chen, M. Tao, J. Ma and J. Zhao, Optimization on condition of epigallocatechin-3-gallate (EGCG) nanoliposomes by response surface methodology and cellular uptake studies in Caco-2 cells, Nanoscale Res. Lett., 2014, 9(1), 291.

34 T. Liang, R. Guan, H. Shen, Q. Xia and M. Liu, Optimization of Conditions for Cyanidin-3-O-Glucoside (C3G) Nanoliposome Production by Response Surface Methodology and Cellular Uptake Studies in Caco-2 Cells, Molecules, 2017, 22(3), 457.

35 E. Arab Tehrany, C. J. Kahn, C. Baravian, B. Maherani, N. Belhaj, X. Wang, et al., Elaboration and characterization of nanoliposome made of soya; rapeseed and salmon lecithins: application to cell culture, Colloids Surf., B, 2012, 95, 75-81.

36 S. Geng, Y. Chen, A. M. Abbasi, H. Ma, H. Mo and B. Liu, Tannin fraction from Ampelopsis grossedentata leaves tea (Tengcha) as an antioxidant and $\alpha$-glucosidase inhibitory nutraceutical, Int. J. Food Sci. Technol., 2016, 51(12), 26922700 .

37 S. Y. Chay, W. K. Tan and N. Saari, Preparation and characterisation of nanoliposomes containing winged bean seeds bioactive peptides, J. Microencapsulation, 2015, 32(5), 488-495.

38 H. Kelebek, S. Selli, P. Kadiroğlu, O. Kola, S. Kesen, B. Uçar, et al., Bioactive compounds and antioxidant potential in tomato pastes as affected by hot and cold break process, Food Chem., 2017, 220, 31-41.

39 N. Liang, W. Xue, P. Kennepohl and D. D. Kitts, Interactions between major chlorogenic acid isomers and chemical changes in coffee brew that affect antioxidant activities, Food Chem., 2016, 213, 251-259.

40 M. M. B. Almeida, P. H. M. de Sousa, Â. M. C. Arriaga, G. M. do Prado, C. E. d. C. Magalhães, G. A. Maia, et al., Bioactive compounds and antioxidant activity of fresh exotic fruits from northeastern Brazil, Food Res. Int., 2011, 44(7), 2155-2159.

41 V. Sicari, T. M. Pellicanò, A. M. Giuffrè, C. Zappia and M. Capocasale, Bioactive compounds and antioxidant activity of citrus juices produced from varieties cultivated in Calabria, J. Food Meas. Charact., 2016, 10(4), 773-780.

42 E. Roka, Z. Ujhelyi, M. Deli, A. Bocsik, E. Fenyvesi, L. Szente, et al., Evaluation of the Cytotoxicity of alpha-Cyclodextrin Derivatives on the Caco-2 Cell Line and Human Erythrocytes, Molecules, 2015, 20(11), 20269-20285.

43 F. Bonnier, M. E. Keating, T. P. Wrobel, K. Majzner, M. Baranska, A. Garcia-Munoz, et al., Cell viability assessment using the Alamar blue assay: a comparison of 2D and 3D cell culture models, Toxicol. In Vitro, 2015, 29(1), 124-131.

44 R. Guan, T. Kang, F. Lu, Z. Zhang, H. Shen and M. Liu, Cytotoxicity, oxidative stress, and genotoxicity in human 
hepatocyte and embryonic kidney cells exposed to $\mathrm{ZnO}$ nanoparticles, Nanoscale Res. Lett., 2012, 7(1), 602.

45 S. Feng, Y. Jin, M. Cui and J. Zheng, Lysine-Specific Demethylase 1 (LSD1) Inhibitor S2101 Induces Autophagy via the AKT/mTOR Pathway in SKOV3 Ovarian Cancer Cells, Med. Sci. Monit., 2016, 22, 4742-4748.

46 H. Yang, L. Qiu, L. Zhang, G. Lv, K. Li, H. Yu, et al., Platinum-zoledronate complex blocks gastric cancer cell proliferation by inducing cell cycle arrest and apoptosis, Tumor Biol., 2016, 37(8), 10981-10992.

47 L. Zhao, S. Wang and Y. Huang, Antioxidant function of tea dregs protein hydrolysates in liposome-meat system and its possible action mechanism, Int. J. Food Sci. Technol., 2014, 49(10), 2299-2306.
48 D. C. Christodouleas, C. Fotakis, A. Nikokavoura and K. Papadopoulos, Calokerinos AC. Modified DPP. H and ABTS Assays to Assess the Antioxidant Profile of Untreated Oils, Food Analytical Methods, 2015, 8(5), 1294-1302.

49 C. Pei-Ni, C. Shu-Chen, C. Hui-Ling, C. Chui-Liang, Y. ShunFa and H. Yih-Shou, Cyanidin 3-Glucoside and Peonidin 3Glucoside Inhibit Tumor Cell Growth and Induce Apoptosis In Vitro and Suppress Tumor Growth In Vivo, Nutr. Cancer, 2005, 53(2), 232-243.

50 A. Sousa, P. Araújo, J. Azevedo, L. Cruz, I. Fernandes, N. Mateus, et al., Antioxidant and antiproliferative properties of 3-deoxyanthocyanidins, Food Chem., 2016, 192, 142-148. 